\title{
Upfront surgery as first-line therapy in selected patients with stage IIIA non-small cell lung cancer
}

\author{
Difan Zheng, MD, Ting Ye, MD, Hong Hu, MD, Yawei Zhang, MD, Yihua Sun, MD, Jiaqing Xiang, MD, \\ and Haiquan Chen, MD
}

\section{ABSTRACT}

Objective: Surgery plays an important role in the multidisciplinary treatment strategy for patients with stage IIIA non-small cell lung cancer (NSCLC). Besides induction therapy, patients could benefit from surgery followed by adjuvant chemotherapy and radiotherapy. This study analyzed a subset of patients with pIIIA NSCLC who underwent upfront surgery as first-line therapy.

Methods: Selected patients with pIIIA NSCLC who received upfront surgery were retrospectively analyzed. Clinicopathologic characteristics and survival outcomes including progression-free survival (PFS) and overall survival (OS) were evaluated.

Results: A total of 668 patients were identified. Five hundred sixty-five patients received adjuvant chemotherapy, and 157 patients received adjuvant radiotherapy after surgery. The median PFS and OS were 17.0 and 44.0 months, respectively. The 3-year and 5-year PFS rates were $31.6 \%$ and $21.0 \%$, and the 3-year and 5year OS rates were $54.7 \%$ and $43.0 \%$. Patients with adenocarcinoma (AD) had better OS than those with squamous cell carcinoma (5-year OS: $P=.026$ ). Patients with low-grade AD (acinar and papillar) had a similar PFS and OS compared with patients with high-grade $\mathrm{AD}$ (solid, micropapillary, and mucinous) (5-year PFS: $P=.894$; 5-year OS: $P=.439$ ). Patients with mutated epidermal growth factor receptor had a similar OS to patients with wild-type epidermal growth factor receptor (5-year OS: $P=.121$ ). Patients with clinical N0 status $(P=.004)$ and patients with single-station of pathologic N2 $(P<.001)$ had better OS.

Conclusions: Upfront surgery followed by adjuvant therapy may provide favorable survival outcomes for selected patients with pIIIA NSCLC, especially for patients with $\mathrm{AD}$ or patients with clinical N0 and pathologic single-station N2 diseases. (J Thorac Cardiovasc Surg 2018;155:1814-22)

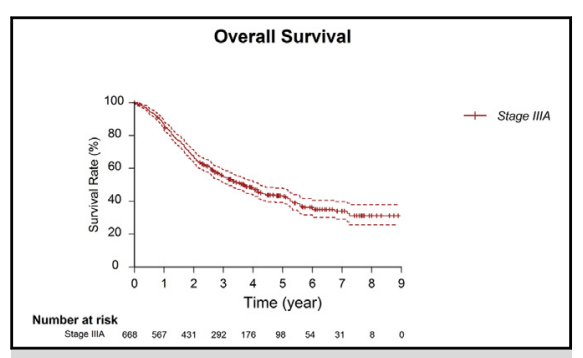

Survival curve of overall survival of patients with IIIA non-small cell lung cancer.

\section{Central Message}

Upfront surgery could provide favorable survival outcomes for selected patients with pIIIA non-small cell lung cancer, especially for patients with adenocarcinoma, or patients with $\mathrm{cN} 0$ and single-station $\mathrm{pN} 2$ diseases

\section{Perspective}

Patients with stage IIIA non-small cell lung cancer have various survival outcomes depending on different subgroups. Treatment should be considered individualized. Surgery plays an important role in the multidisciplinary treatment strategy. Besides induction therapy, a subset of selected patients could benefit from upfront surgery followed by adjuvant chemotherapy and radiotherapy.

See Editorial Commentary page 1823.
From the Department of Thoracic Surgery, Fudan University Shanghai Cancer Center, Shanghai, China; and Department of Oncology, Fudan University Shanghai Medical College, Shanghai, China.

This work was funded by the National Natural Science Foundation of China (81330056, 81572253, 81372525, 81422029, and 81572264), the National Science Foundation for Young Scholars of China (Grant No. 81302008), and a grant from the Health and Family Planning Commission of Shanghai Municipality (No. 2013ZYJB0301).

Drs Zheng and Ye contributed equally to this work.

Received for publication Dec 13, 2016; revisions received Sept 23, 2017; accepted for publication Oct 13, 2017; available ahead of print Dec 6, 2017.

Address for reprints: Haiquan Chen, MD, Department of Thoracic Surgery, Fudan University Shanghai Cancer Center, 270 Dong'an Rd, Shanghai, China 200032 (E-mail: hqchen1@yahoo.com).

$0022-5223 / \$ 36.00$

Copyright (c) 2017 by The American Association for Thoracic Surgery

https://doi.org/10.1016/j.jtcvs.2017.10.075
Treatment for patients with stage IIIA lung cancer remains one of the most challenging domains in thoracic oncology, in view of the intrinsic heterogeneity of this population. Multidisciplinary therapy based on chemotherapy, radiotherapy, or chemoradiotherapy combined with surgery was regarded as the standard option during the last 2 decades. $^{1-3}$ However, the optimal combination and sequence of these 3 options pose an ongoing challenge in

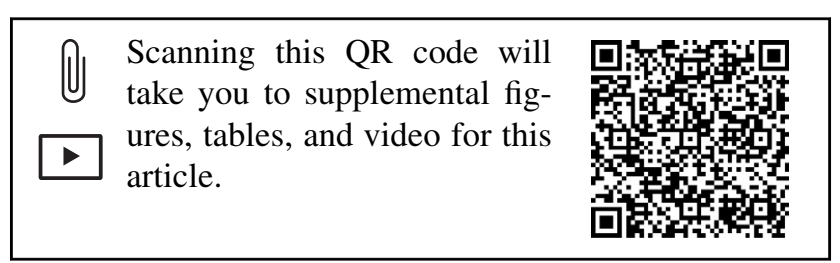




$$
\begin{aligned}
& \text { Abbreviations and Acronyms } \\
& \begin{aligned}
\mathrm{AD} & =\text { adenocarcinoma } \\
\mathrm{CI} & =\text { confidence interval } \\
\mathrm{CT} & =\text { computed tomography } \\
\mathrm{EGFR} & =\text { epidermal growth factor receptor } \\
\mathrm{HR} & =\text { hazard ratio } \\
\text { NSCLC } & =\text { non-small cell lung cancer } \\
\mathrm{OS} & =\text { overall survival } \\
\mathrm{PFS} & =\text { progression-free survival } \\
\mathrm{PRS} & =\text { postrecurrent-free survival } \\
\mathrm{SCC} & =\text { squamous cell carcinoma }
\end{aligned}
\end{aligned}
$$

clinical practice. First, most guidelines recommended induction treatment followed by surgical resection, but that the data supporting this approach compared with surgery followed by adjuvant treatment were mixed. In addition, the addition of radiotherapy to induction chemotherapy failed to improve survival compared with induction chemotherapy alone. ${ }^{4,5}$ Moreover, 2 randomized clinical trials showed that induction chemoradiotherapy plus surgery failed to present a survival benefit compared with definitive chemoradiotherapy. Although preoperative treatment did not increase the complexity of surgery or surgical-related adverse events, there were still some clinical trials that reported a greater perioperative mortality and morbidity. ${ }^{6,7}$ Furthermore, patients with incidentally discovered microscopic IIIA tumor could greatly benefit from initial surgical resection even without induction treatment. $^{8}$

This dilemma was primarily caused by the heterogeneous subgroups of this disease. Therefore, the identification of certain patients with stage IIIA non-small cell lung cancer (NSCLC) who have decent outcomes with appropriate multimodality regimens and who have the best chance of longterm survival with surgery is necessary. In this study, we analyzed the characteristics and prognosis of a subset of patients with pIIIA NSCLC who underwent upfront surgery as first-line therapy. The aim of this study was to explore the role of upfront surgery in treating selected patients with pIIIA NSCLC.

\section{PATIENTS AND METHODS \\ Patients}

We prospectively collected data and retrospectively identified consecutive patients with pIIIA (including $\mathrm{T}_{1-3} \mathrm{~N}_{2}, \mathrm{~T}_{3-4} \mathrm{~N}_{1}, \mathrm{~T}_{4} \mathrm{~N}_{0}$ ) NSCLC between August 2006 and December 2013 from the medical records at Fudan University Shanghai Cancer Center. All patients were initially treated with surgery. Those patients who received induction therapy were excluded from this study. Most of the patients received adjuvant chemotherapy or selective radiotherapy after surgery. Of these patients, survival data and clinicopathologic material were collected and evaluated.

Patients were preoperatively staged and evaluated according to routine protocol, which included enhanced chest computed tomography (CT) scan, enhanced brain magnetic resonance imaging or $\mathrm{CT}$ scan, bone scanning, abdominal CT or ultrasonography, fiberoptic bronchoscopy, and cardiopulmonary tests. Positron emission tomography-CT was performed on highly suspicious patients with bulky mediastinal mass (tumor mass within the mediastinum such that discrete lymph nodes cannot be distinguished or measured). A patient's clinical stage was mainly assessed by chest CT scan. Patients whose tumors were considered initially unresectable received invasive mediastinal staging operations to receive pathology confirmation followed by induction therapy. These patients were excluded from this study.

A group of experienced thoracic surgeons performed surgeries. Videoassisted thoracic surgery or subaxillary muscle-sparing minithoractomy was performed, and intraoperative frozen section was routinely performed. ${ }^{9}$ Once lung cancer was confirmed during the surgery, lobectomy with systematic mediastinal lymph node dissection was considered the standard operation (Video 1) and extension of anatomical pulmonary resection (bilobectomy or pneumonectomy) was performed if necessary (see flowchart in Figure 1). The systematic mediastinal and hilar lymphadenectomy (station 2, 3a, 4, 7, 8, 9, 10, and 11 on the right; station 5, 6, 7, 8, 9, 10, and 11 on the left) was strictly operated. Classification of lymph node station was based on the International Association for the Study of Lung Cancer lymph node map. ${ }^{10}$ All patients' pathologic tumor, node, and metastasis stages were restaged according to the seventh edition of The Lung Cancer Staging Classification System. Lung adenocarcinoma (AD) specimens before 2011 were reviewed according to the 2011 classification of $\mathrm{AD}^{11}$

This study was conducted in line with the Declaration of Helsinki and was approved by the Institutional Review Board of the Fudan University Shanghai Cancer Center (Fudan University Shanghai Cancer Center IRB\# 090977-1). Written informed consent was obtained from each patient to allow their biological samples to be genetically analyzed.

\section{Follow-up}

Patients were regularly followed every $3 \pm 1$ months during the first 3 years postoperatively. Enhanced chest CT scan and abdominal

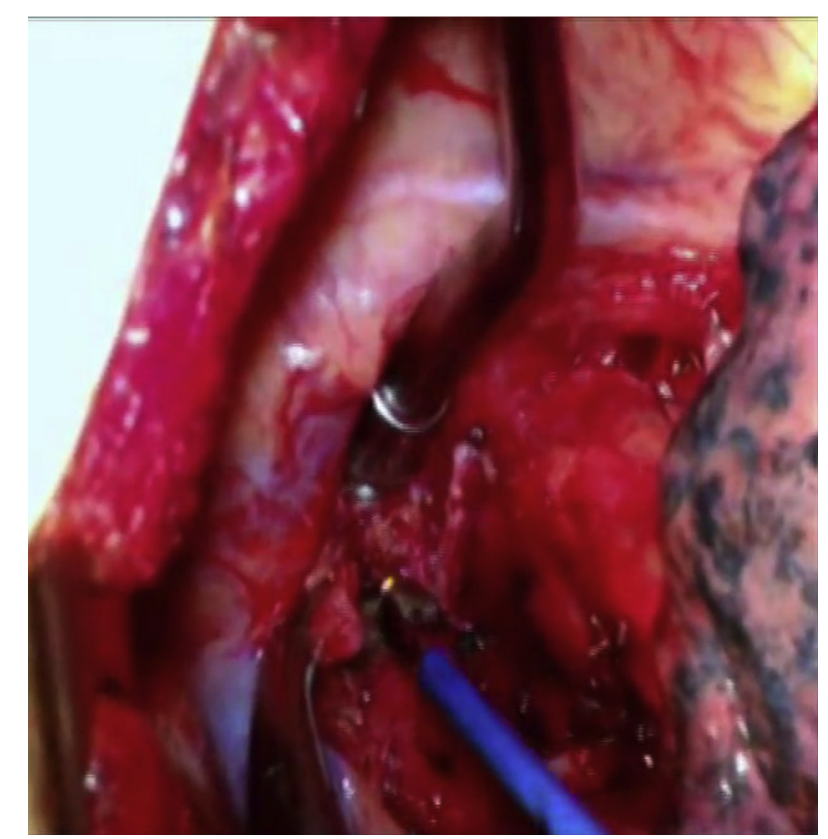

VIDEO 1. Subaxillary muscle-sparing minithoractomy and right upper lobectomy with upper mediastinal lymph node (group 2-4) dissection. Video available at: http://www.jtcvsonline.org/article/S0022-5223(17)32409-1/ fulltext. 


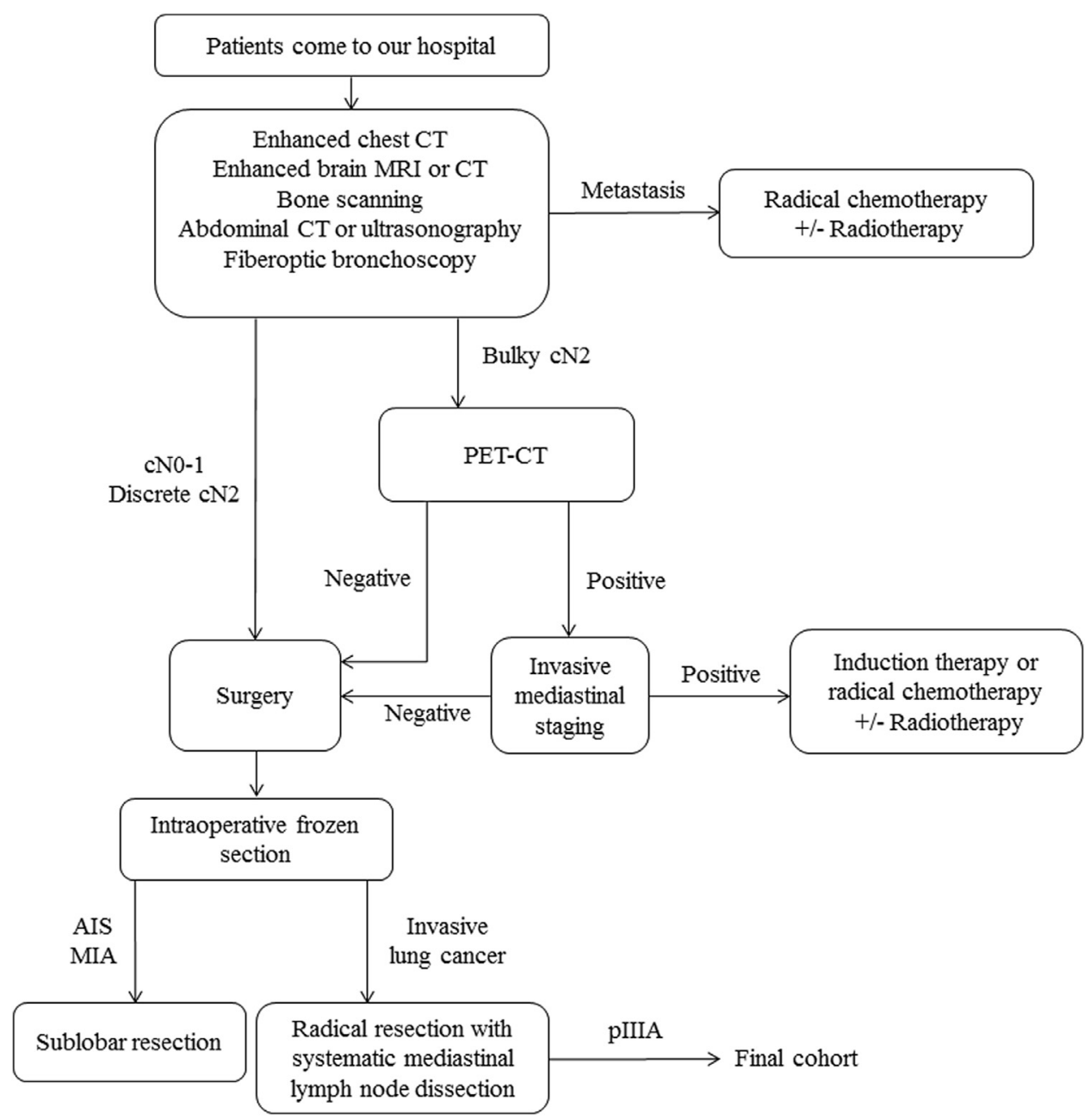

FIGURE 1. Flowchart of clinical treatment strategy. CT, Computed tomography; MRI, magnetic resonance imaging; PET-CT, positron emission tomography-computed tomography; $A I S$, adenocarcinoma in situ; MIA, minimally invasive adenocarcinoma.

ultrasonography were performed every $3 \pm 1$ months, whereas brain magnetic resonance imaging and bone scanning were required every $6 \pm 1$ months. From the third year after surgery, the follow-up period extended to every $6 \pm 1$ months, and every $12 \pm 3$ months from the sixth year. If tumor recurrence was suspected, pathologic confirmation was usually obtained. Follow-up was performed via the outpatient clinic visit and telephone calls.

\section{Statistical Analysis}

All data were recorded in Excel 2010 (Microsoft, Redmond, Wash) and analyzed with SPSS 16.0 (SPSS Inc, Chicago, Ill). A descriptive analysis was carried out in which categorical variables were expressed as absolute and relative frequencies and continuous variables as means $\pm \mathrm{SD}$. The primary endpoints were progression-free survival (PFS) and overall survival (OS). PFS was measured from the date of operation until the date of first progression or recurrence or death from any cause. OS was measured from the date of operation until the date of death from any cause or the date last seen alive.

Survival curves of PFS and OS were estimated by the Kaplan-Meier method. Differences in survival were assessed by the log-rank test. Variables with a $P$ value less than .05 were entered into the Cox proportional hazards regression model for the multivariate analysis for prognostic factors. We used forward stepwise selection that formed stepwise selection procedures with the likelihood ratio test. Factors statistically significant at the .05 level remained in the final model. The statistical results were expressed by $95 \%$ confidence intervals (CIs).

\section{RESULTS}

A total of 668 patients who received surgical resection at Department of Thoracic Surgery, Fudan University Shanghai Cancer Center and were pathologically confirmed as IIIA NSCLC were identified and included in this study. Their detailed characteristics were summarized in Table 1 . The majority of patients $(n=613 ; 91.8 \%)$ received $\mathrm{R} 0$ resection. The mean number of the resected lymph nodes were $20.4 \pm 10.0$, with a mean of $5.7 \pm 5.9$ metastasized lymph nodes. $\mathrm{AD}(\mathrm{n}=434 ; 65.0 \%)$ and squamous cell carcinoma (SCC; $n=181 ; 27.1 \%$ ) were the predominant pathologic subtypes. Three hundred two patients with clinical N2 $(45.2 \%)$ and 366 patients with clinical N0 (54.8\%) were identified preoperatively. Six hundred twenty-eight patients with pathologic $\mathrm{N} 2$ diseases $(94.0 \%)$ ) were postoperatively confirmed. Five hundred sixty-five patients 
TABLE 1. Clinicopathologic characteristics of subjects in this study

\begin{tabular}{|c|c|}
\hline Parameter & n $(\%)$ \\
\hline Number & 668 \\
\hline \multicolumn{2}{|l|}{ Age, y } \\
\hline Median & 59 \\
\hline Mean \pm SD & $59 \pm 9.7$ \\
\hline Range & $22-86$ \\
\hline \multicolumn{2}{|l|}{ Sex } \\
\hline Male & $415(62.1)$ \\
\hline Female & $253(37.9)$ \\
\hline \multicolumn{2}{|l|}{ Smoking status } \\
\hline Smoker & $341(51.0)$ \\
\hline Never-smoker & $327(49.0)$ \\
\hline \multicolumn{2}{|l|}{ Tumor location } \\
\hline Peripheral & $510(76.3)$ \\
\hline Central & $158(23.7)$ \\
\hline \multicolumn{2}{|l|}{ Surgical approach } \\
\hline VATS & $49(7.3)$ \\
\hline Muscle-sparing minithoractomy & $619(92.7)$ \\
\hline \multicolumn{2}{|l|}{ Resection extent } \\
\hline Lobectomy & $512(76.6)$ \\
\hline Bilobectomy & $86(12.9)$ \\
\hline Pneumonectomy & $70(10.5)$ \\
\hline \multicolumn{2}{|l|}{ Margin } \\
\hline Positive & $55(8.2)$ \\
\hline Negative & $613(91.8)$ \\
\hline \multicolumn{2}{|l|}{ Pathologic subtype } \\
\hline Adenocarcinoma & $434(65.0)$ \\
\hline Squamous cell carcinoma & $181(27.1)$ \\
\hline Adenosquamous carcinoma & $27(4.0)$ \\
\hline Large cell lung cancer & $18(2.7)$ \\
\hline Other subtypes & $8(1.2)$ \\
\hline \multicolumn{2}{|l|}{ Clinical N2 status } \\
\hline No & $366(54.8)$ \\
\hline $\mathrm{N} 2$ & $302(45.2)$ \\
\hline \multicolumn{2}{|l|}{ TNM stage (seventh) } \\
\hline $\mathrm{T} 1-3 \mathrm{~N} 2$ & $628(94.0)$ \\
\hline T3-4N1 & $37(5.5)$ \\
\hline T4N0 & $3(0.4)$ \\
\hline \multicolumn{2}{|l|}{ Pathologic N2 status } \\
\hline Single-station & $337(50.4)$ \\
\hline Multistation & $291(43.6)$ \\
\hline \multicolumn{2}{|l|}{ Adjuvant chemotherapy } \\
\hline Yes & $565(84.6)$ \\
\hline No (including unknown) & $103(15.4)$ \\
\hline \multicolumn{2}{|l|}{ Adjuvant radiotherapy } \\
\hline Yes & $157(23.5)$ \\
\hline No & $511(76.5)$ \\
\hline
\end{tabular}

$S D$, Standard deviation; VATS, video-assisted thoracoscopy; TNM, tumor, node, and metastasis.

$(84.6 \%)$ received adjuvant chemotherapy, and 157 patients $(23.5 \%)$ received adjuvant radiotherapy after surgery. Six patients $(0.9 \%)$ died within 1 month after surgery. Of these 6,3 patients died due to surgery and another 3 patients died due to tumor progression. The latter 3 did not receive radical resection, and their tumors progressed rapidly after surgery.

\section{Progression-Free Survival}

Six hundred fifty-three patients $(97.8 \%)$ were regularly followed at the outpatient clinic and by telephone contact. Fifteen patients $(2.2 \%)$ were lost during the follow-up period or because the follow-up time was less than 12 months. Four hundred thirty-two (cumulative incidence of recurrence at year 5: 69.7\%) patients experienced tumor recurrence within 5 years after radical resection. More than $40 \%$ of these patients primarily had tumor recurrence in lung or superficial lymph node, all with pathologic confirmation. Patients whose tumor recurred in brain, bone, or abdominal organs were confirmed by the multidisciplinary tumor board, mainly based on the dynamic changes in imaging, tumor functional imaging, or liquid biopsy. The median PFS was 17.00 months (95\% CI, 14.80-19.20). The 3-year and 5-year PFS rate was $31.6 \%$ and $21.0 \%$, respectively (Figure 2, A). On univariable analysis, large tumor size $(P=.010)$, clinical N2 status $(P=.002)$, multistation of pathologic N2 $(P<.001)$, muscle-sparing minithoractomy $(P=.029)$, and without adjuvant chemotherapy $(P=.010)$ were correlated with a greater risk of progression. On multivariable analysis, large tumor size (hazard ratio [HR], 1.232; 95\% CI, 1.018-1.492; $P=.032$ ), clinical N2 status (HR, $1.220 ; 95 \%$ CI, $1.006-$ $1.479 ; P=.043$ ), multistation of pathologic N2 (HR, 1.456; 95\% CI, 1.204-1.760; $P<.001)$, and without adjuvant chemotherapy (HR, 1.311; 95\% CI, 1.002-1.715; $P=.049)$ were independently associated with worse PFS (Tables E1 and E2).

\section{Overall Survival}

Three hundred eighteen patients were alive or censored during the follow-up period. Three hundred forty-three $(51.3 \%)$ patients died as the result of tumor progression. Seven $(1.0 \%)$ patients died due to other causes, including gastric bleeding, bowel obstruction, fever, heart disease, and accident. The median OS was 44.0 months $(95 \% \mathrm{CI}$, $37.78-50.22$ ). The 3-year and 5-year OS rates were $54.7 \%$ and $43.0 \%$, respectively (Figure $2, B$ ). On univariable analysis, age older than 65 years $(P=.001)$, smoker $(P=.032)$, clinical N2 status $(P=.004)$, muscle-sparing minithoractomy $(P=.004)$, pneumonectomy or bilobectomy $(P<.001)$, tumor larger than $3 \mathrm{~cm}(P=.010)$, non-AD $(P=.008), \mathrm{R} 1$ or $\mathrm{R} 2$ resection $(P<.001)$, multistation of pathologic N2 $(P<.001)$, and without adjuvant chemotherapy $(P<.001)$ were associated with worse OS. On multivariable analysis, older age (HR, $1.308 ; 95 \% \mathrm{CI}$, $1.006-1.702 ; P=.045)$, smoker (HR, $1.277 ; 95 \% \mathrm{CI}$, 1.018-1.601; $P=.035)$, multistation of pathologic N2 (HR, 1.671; 95\% CI, 1.338-2.088; $P<.001$ ), positive margin (HR, 1.425; 95\% CI, 1.188-1.709; $P<.001)$, and 

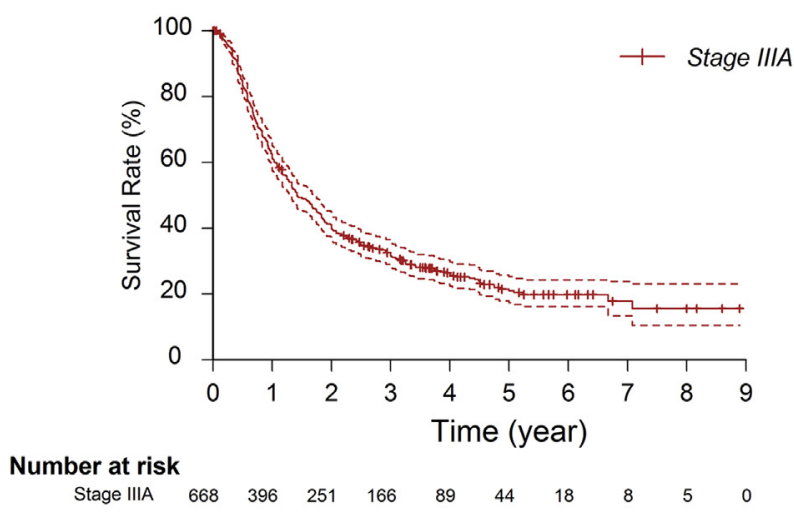

A

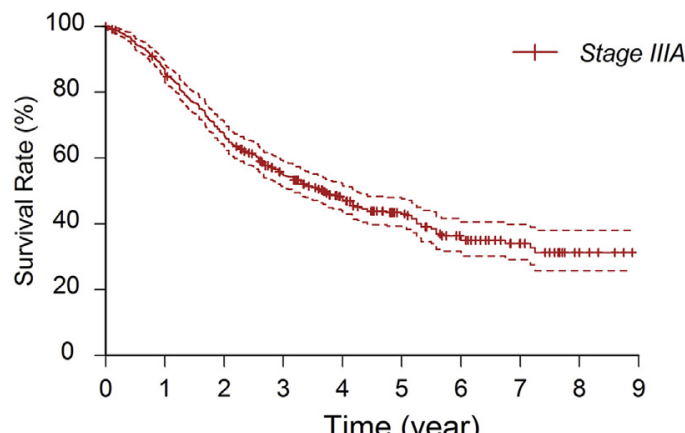

Number at risk

B

$\begin{array}{lllllllllll}\text { Stage IIIA } & 668 & 567 & 431 & 292 & 176 & 98 & 54 & 31 & 8 & 0\end{array}$

FIGURE 2. A, Survival curve of progression-free survival of patients with IIIA NSCLC. B, Survival curve of overall survival of patients with IIIA NSCLC. The colored dotted lines represent the $95 \%$ confidence interval for each curve.

without adjuvant chemotherapy (HR, 1.976; 95\% CI, $1.468-2.660 ; P<.001)$ were independently associated with worse OS (Tables E1 and E2).

\section{AD and SCC}

Four hundred thirty-four patients with lung AD and 181 patients with lung SCC were pathologically confirmed. Their characteristics were listed in Table 2. Compared with lung SCC, lung AD was more commonly seen in female patients $(P<.001)$ and never-smokers $(P<.001)$. In addition, the tumor always showed peripheral location (located in or more peripheral to the subsegmental bronchus) $(P<.001)$, small size $(P<.001)$, but more $\mathrm{N} 2$ involvement $(P<.001)$. Patients with $\mathrm{AD}$ had inferior 5-year PFS to patients with SCC $(18.0 \%$ vs $29.4 \%)$, although there was no statistical significance $(P=.162)$ (Figure 3, A). However, patients with $\mathrm{AD}$ had better 5year OS than those with SCC $(45.2 \%$ vs $40.6 \%$; $P=.026$ ) (Figure 3, B). Moreover, we evaluated the postrecurrent-free survival (PRS) in these patients and found that patients with AD had a much better PRS than those with SCC (median PRS: $19 \pm 1.5$ vs
$7.4 \pm 1.3$ months; $P<.001$ ) (Figure 4). According to the International Association for the Study of Lung Cancer/ American Thoracic Society/European Respiratory Society classification, ${ }^{11}$ there were no lepidic predominant, 194 acinar predominant, 73 papillar predominant, 132 solid predominant, 17 micropapillar predominant, and 18 mucinous subtypes in all ADs. In this study, acinar predominant and papillar predominant subtypes were classified as the low-grade AD $(n=267)$, whereas solid predominant, micropapillar predominant, and mucinous subtypes were classified as the high-grade AD $(n=167) .{ }^{12}$ Compared with the high-grade $\mathrm{AD}$, the low-grade $\mathrm{AD}$ had more small-sized lesions $(P<.001)$, peripheral-located tumors $(P=.047)$, and epidermal growth factor receptor (EGFR) mutations $(P<.001)$. When analyzing PFS and OS by the architectural grade, we found that patients with lowgrade tumors had a similar PFS compared with those with high-grade tumors (5-year PFS rate: $16.4 \%$ vs $20.7 \%, P=.894)$. Patients with low-grade tumors had a superior OS compared with those with high-grade tumors (5year OS rate: $48.0 \%$ vs $39.2 \%, P=.439$ ), although there was no statistical significance (Table E3 and Figure E1). When we analyzed OS by EGFR mutation, patients with mutated EGFR also had a similar OS to patients with wild-type EGFR (5-year OS rate: $47.7 \%$ vs $42.1 \%$; $P=.121$ ) (Figure E2).

\section{Clinical N2 and Pathologic N2 Diseases}

Three hundred forty patients with preoperative N0 status were postoperatively confirmed $\mathrm{N} 2$ diseases in this study. These patients had a better PFS and OS than those with preoperative N2 diseases (5-year PFS rate: $22.6 \%$ vs $17.8 \%$, $P=.003$; 5-year OS rate: $49.8 \%$ vs $35.5 \%, P=.004$ ) (Figure E3). Moreover, for patients with pathologic N2 diseases, patients with single-station N2 had the significantly better PFS and OS than those with multistation N2 (5-year PFS rate: $25.6 \%$ vs $13.1 \%, P<.001$; 5-year OS rate: $55.7 \%$ vs $28.5 \%, P<.001$ ) (Figure $\mathrm{E} 4$ ).

\section{DISCUSSION}

Given the excellent results from the National Lung Screening Trial, detection and treatment of early-stage lung cancer have been improved, and the mortality of lung cancer has been reduced in recent years. ${ }^{13,14}$ However, advanced-stage lung cancer, especially those tumors with mediastinal lymph node involvement, is still commonly seen in real-world clinical practice. Treatment strategy for stage IIIA NSCLC is controversial, considering the intrinsic heterogeneity of this disease. These debates remain even in stage IIIA-N2 NSCLC.

In the early 1990s, 2 small randomized control trials conducted by Roth and colleagues ${ }^{15}$ and Rosell and colleagues ${ }^{16}$ reported the excellent results of induction chemotherapy followed by resection for patients with stage 
TABLE 2. Comparison of characteristics of patients with lung AD and SCC

\begin{tabular}{|c|c|c|c|}
\hline Parameter & $\begin{array}{c}\text { AD } \\
(n=434) \\
n(\%)\end{array}$ & $\begin{array}{c}\text { SCC } \\
(\mathbf{n}=181) \\
\text { n }(\%)\end{array}$ & $P$ value \\
\hline Age, mean $\pm \mathrm{SD}$ & $58.5 \pm 10.1$ & $60.2 \pm 8.5$ & $.034 *$ \\
\hline $\begin{array}{l}\text { Sex } \\
\qquad \text { Male } \\
\text { Female }\end{array}$ & $\begin{array}{l}216(49.8) \\
218(50.2)\end{array}$ & $\begin{array}{r}162(89.5) \\
19(10.5)\end{array}$ & $<.001 \dagger$ \\
\hline $\begin{array}{l}\text { Smoking status } \\
\text { Smoker } \\
\text { Never-smoker }\end{array}$ & $\begin{array}{l}162(37.3) \\
272(62.7)\end{array}$ & $\begin{array}{r}144(79.6) \\
37(20.4)\end{array}$ & $<.001 \dagger$ \\
\hline $\begin{array}{l}\text { Tumor location } \\
\text { Peripheral } \\
\text { Central }\end{array}$ & $\begin{array}{r}381(87.8) \\
53(12.2)\end{array}$ & $\begin{array}{l}87(48.1) \\
94(51.9)\end{array}$ & $<.001 \dagger$ \\
\hline $\begin{array}{l}\text { Surgical approach } \\
\text { Muscle-sparing } \\
\text { VATS }\end{array}$ & $\begin{array}{r}389(89.6) \\
45(10.4)\end{array}$ & $\begin{array}{c}179(98.9) \\
2(1.1)\end{array}$ & $<.001 \dagger$ \\
\hline $\begin{array}{l}\text { Resection extent } \\
\text { Lobectomy } \\
\text { Bilobectomy } \\
\text { Pneumonectomy }\end{array}$ & $\begin{array}{c}369(85.0) \\
44(10.1) \\
21(4.8)\end{array}$ & $\begin{array}{r}105(58.0) \\
35(19.3) \\
41(22.7)\end{array}$ & $<.001 \dagger$ \\
\hline $\begin{array}{l}\text { Margin } \\
\text { Positive } \\
\text { Negative }\end{array}$ & $\begin{array}{c}23(5.3) \\
411(94.7)\end{array}$ & $\begin{array}{r}30(16.6) \\
151(83.4)\end{array}$ & $<.001 \dagger$ \\
\hline $\begin{array}{l}\text { Tumor size, } \mathrm{cm} \\
\quad \leq 3 \\
>3\end{array}$ & $\begin{array}{l}238(54.8) \\
196(45.2)\end{array}$ & $\begin{array}{r}38(21.0) \\
143(79.0)\end{array}$ & $<.001 *$ \\
\hline $\begin{array}{l}\text { T } \\
\text { T1a } \\
\text { T1b } \\
\text { T2a } \\
\text { T2b } \\
\text { T3 } \\
\text { T4 }\end{array}$ & $\begin{array}{c}67(15.4) \\
78(18.0) \\
208(47.9) \\
30(6.9) \\
47(10.8) \\
4(0.9)\end{array}$ & $\begin{array}{c}5(2.8) \\
20(11.0) \\
62(34.3) \\
35(19.3) \\
55(30.4) \\
4(2.2)\end{array}$ & $<.001 \dagger$ \\
\hline $\begin{array}{l}\text { Clinical N2 status } \\
\text { N0 } \\
\text { N2 }\end{array}$ & $\begin{array}{l}264(60.8) \\
170(39.2)\end{array}$ & $\begin{array}{l}84(46.4) \\
97(53.6)\end{array}$ & $.001 \dagger$ \\
\hline $\begin{array}{l}\text { TNM stage } \\
\text { T1-3N2 } \\
\text { T3-4N1 } \\
\text { T4N0 }\end{array}$ & $\begin{array}{c}420(96.8) \\
13(3.0) \\
1(0.2)\end{array}$ & $\begin{aligned} 159 & (87.8) \\
20 & (11.1) \\
2 & (1.1)\end{aligned}$ & $<.001 \dagger$ \\
\hline $\begin{array}{l}\text { Pathologic N2 status } \\
\text { Single-station } \\
\text { Multistation }\end{array}$ & $\begin{array}{l}213(49.1) \\
208(47.9)\end{array}$ & $\begin{array}{r}104(57.5) \\
56(30.9)\end{array}$ & $.002 \dagger$ \\
\hline $\begin{array}{l}\text { Adjuvant chemotherapy } \\
\text { Yes } \\
\text { No }\end{array}$ & $\begin{array}{r}368(84.8) \\
66(15.2)\end{array}$ & $\begin{array}{r}153(84.5) \\
28(15.5)\end{array}$ & $.934 \dagger$ \\
\hline $\begin{array}{l}\text { Adjuvant radiotherapy } \\
\text { Yes } \\
\text { No }\end{array}$ & $\begin{array}{l}113(26.0) \\
321(74.0)\end{array}$ & $\begin{array}{r}32(17.7) \\
149(82.3)\end{array}$ & $.026^{\dagger}$ \\
\hline
\end{tabular}

TABLE 2. Continued

\begin{tabular}{|c|c|c|c|}
\hline Parameter & $\begin{array}{c}\text { AD } \\
(n=434), \\
n(\%)\end{array}$ & $\begin{array}{c}\text { SCC } \\
(\mathbf{n}=181), \\
\mathbf{n}(\%)\end{array}$ & $P$ value \\
\hline \multicolumn{4}{|l|}{ Survival } \\
\hline 5-y PFS rate & $18.0 \%$ & $29.4 \%$ & $.162 \ddagger$ \\
\hline 5-y OS rate & $45.2 \%$ & $40.6 \%$ & $.026 \ddagger$ \\
\hline Median PRS, mo & $19 \pm 1.5$ & $7.4 \pm 1.3$ & $<.001 \ddagger$ \\
\hline Median PFS, mo & $18.8 \pm 1.5$ & $18.0 \pm 2.8$ & $.162 \ddagger$ \\
\hline Median OS, mo & $50.0 \pm 4.7$ & $33.8 \pm 5.0$ & $.026 \ddagger$ \\
\hline
\end{tabular}

$A D$, Adenocarcinoma; $S C C$, squamous cell cancer; $S D$, standard deviation; VATS, video-assisted thoracoscopy; TNM, tumor, node, and metastasis; PFS, progressionfree survival; $O S$, overall survival; $P R S$, postrecurrent-free survival. *Analyzed by $t$ test. $\dagger$ Analyzed by $\chi^{2}$ test. $\ddagger$ Analyzed by log-rank test.

IIIA-pN2 diseases compared with surgery alone, respectively. There were 60 patients in Roth and colleague's cohort and in Rosell and colleague's cohort. In the study of Roth and colleagues, the 3 -year survival rate was $56 \%$ in perioperative chemotherapy group and $15 \%$ in surgery alone group. However, in the study by Rosell and colleagues, the 3 -year survival rate was $27 \%$ and zero in each group. Surgical mortality in these 2 studies was $5 \%$ and $6.7 \%$, respectively. Both trials stopped early and although they came to the same conclusions, the survival rates presented in these studies were quite different, making the benefit of induction chemotherapy appear unconvincing.

In addition, in 2002 Nagai and colleagues ${ }^{17}$ reported that in patients with stage IIIA N2 NSCLC, induction chemotherapy followed by surgery did not demonstrate a survival benefit compared with surgery alone. In the study of Nagai and colleagues, the 5-year survival rate was $10 \%$ in induction chemotherapy group and $22 \%$ in surgery alone group. The 5-year survival rate in surgery alone group seemed greater than that in induction chemotherapy group, although no statistical significance was reached. The authors attributed the negative result to the poor response to induction chemotherapy. Induction treatment including chemotherapy and/or radiotherapy combined with surgery could be beneficial and feasible for patients with resectable NSCLC. ${ }^{18,19}$ However, different meta-analyses showed opposite results comparing induction chemotherapy followed by surgery with surgery alone. ${ }^{20-22}$ Subgroup analyses of stage IIIA patients were unavailable in the aforementioned literature. Controversies concerning induction chemotherapy in patients with stage IIIA NSCLC remain. Unfortunately, well-powered individual randomized controlled trials that show a clear survival advantage for induction chemotherapy or chemoradiotherapy are still unavailable.

According to previous reports, patients with stage IIIApN2 NSCLC who received preoperative chemotherapy or 


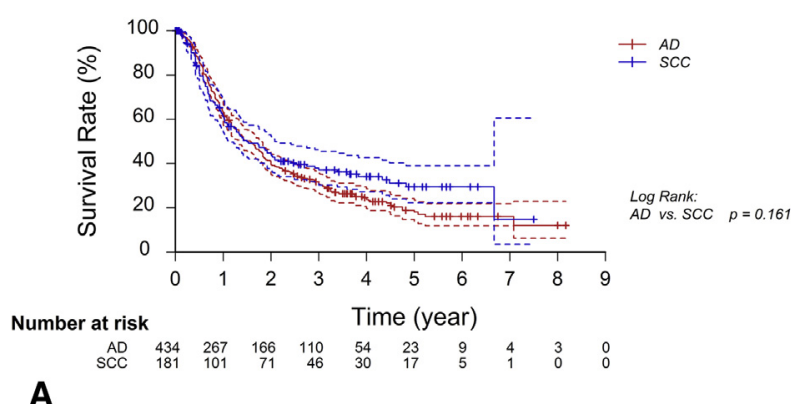

A

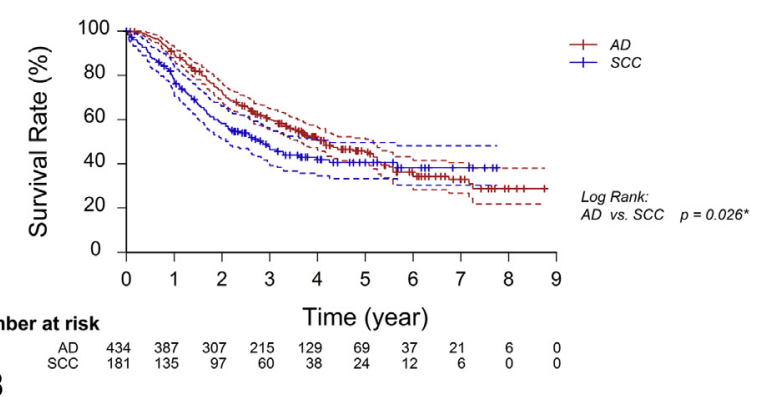

FIGURE 3. A, Comparison of progression-free survival of patients with AD and patients with SCC. B, Comparison of overall survival of patients with $\mathrm{AD}$ and patients with SCC. The colored dotted lines represent the $95 \%$ confidence interval for each curve. $A D$, Adenocarcinoma; $S C C$, squamous cell cancer.

chemoradiotherapy combined with surgical resection had a median OS of nearly 25 months , $^{6,23-26}$ (Table 3 ). Recently, a multicenter, phase 3 randomized trial revealed that patients with stage IIIA-pN2 NSCLC who received induction chemotherapy and surgery had a median OS of 26.2 months, whereas patients who received induction chemoradiotherapy had a median OS of 37.1 months. This survival difference was statistically insignificant. ${ }^{5}$ In 2012, Japanese colleagues reported a nationwide analysis for patients with stage IIIA-cN2/pN2 NSCLC. Their results showed that patients receiving induction treatment had a 5-year survival rate of $28.1 \%$, patients receiving adjuvant chemotherapy had a 5-year survival rate of $27.8 \%$, and patients who underwent surgery alone had a 5 -year survival rate of $33.7 \%$. Therefore, regarding patients with IIIA-cN2/pN2

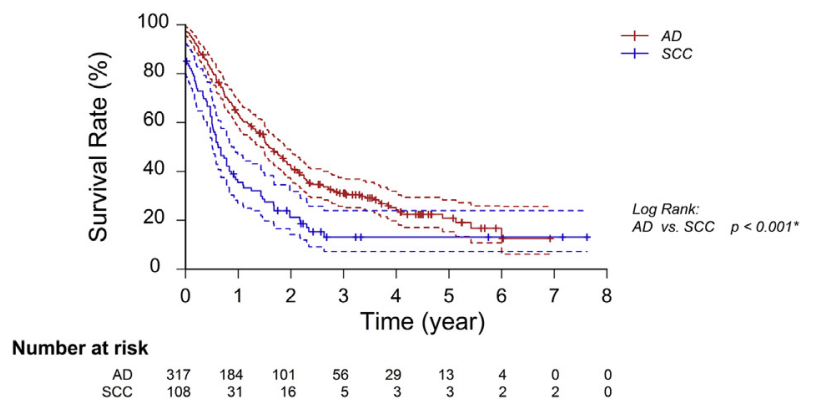

FIGURE 4. Comparisons of postrecurrent-free survival of patients with $\mathrm{AD}$ and patients with SCC. The colored dotted lines represent the $95 \%$ confidence interval for each curve. $A D$, Adenocarcinoma; $S C C$, squamous cell cancer
NSCLC, surgery alone could provide favorable survival in comparison with those previously reported. However, in that study, only $34.6 \%$ patients received adjuvant chemotherapy, in whom 38 patients received oral chemotherapy. ${ }^{27}$ Sophisticated selection of surgical candidate is important for patients with stage IIIA NSCLC, but postoperative adjuvant therapy is essential. ${ }^{28}$

In the present study, we retrospectively analyzed 668 patients with stage IIIA NSCLC. These patients were either in $\mathrm{cN} 0-1 / \mathrm{pN} 2$ or minimal $\mathrm{N} 2$ status by imaging evaluation preoperatively, and their tumors were considered initially resectable. Based on our treatment strategy, patients who were diagnosed with invasive lung cancer during surgery were subject to systematic lymph node dissection. Therefore, preoperative lymph node condition in these patients had little impact on our surgical procedure selection. Invasive mediastinal staging of lung cancer through mediastinoscopy endobronchial ultrasound-guided transbronchial needle aspiration or endoscopic ultrasound-guided needle aspiration not included in our treatment strategy, although most physicians believed that it was an important part of modern thoracic surgical oncology. ${ }^{29,30}$ Only initially unresectable patients received invasive mediastinal staging operations, whereas those patients with positive pathologic confirmations were initially given chemotherapy or induction chemotherapy.

Our strategy was slightly different from the current guidelines. ${ }^{31-33}$ It was based on these strict criteria that patients included in this study could achieve favorable surgical outcomes. Ninety-four percent of the patients were IIIA-pN2 diseases. This subgroup of patients had a median PFS of 17.0 months and median OS of 44.0 months. Compared with previous reports (Table E2), this high OS rate might attribute to a high rate of $\mathrm{cN} 0-1$ patients in our study cohort. Moreover, for patients with clinical N2 diseases, the median PFS was 14.0 months and median OS was 34.9 months, respectively. Even for patients with multistation N2 involvement, the median PFS and OS were 13.8 months and 32.0 months, respectively. These results were unexpected but encouraging. Because of the postoperative adjuvant therapy and administration of EGFR-TKI for EGFR mutant lung $\mathrm{AD}$, patients with stage IIIA-pN2 NSCLC received upfront surgery could achieve comparable or superior survival outcomes. Tumor size and lymph node status were the 2 most important prognostic factors for this disease, since with the surgical approach, extent and margin were determined by $\mathrm{T}$ and $\mathrm{N}$ status. Our data showed that even for T1a tumors, multistation mediastinal lymph node metastasis may occur anyway. Hence, tumor size was not an effective determinant for the final stage. Meticulous surgery including thorough mediastinal lymph nodes dissection was the "cornerstone." In this study, each included patient received "aggressive" mediastinal lymphadenectomy, with an average of 20 lymph nodes resected. The 
TABLE 3. World literature comparing the outcomes of surgery for stage IIIA-pN2 NSCLC

\begin{tabular}{|c|c|c|c|c|c|c|c|c|}
\hline Author & Year & Study type & $\begin{array}{c}\text { Number of } \\
\text { patients }\end{array}$ & $\begin{array}{l}\text { Induction } \\
\text { therapy }\end{array}$ & $\begin{array}{c}\text { Outcome, } \\
\text { median }\end{array}$ & $\begin{array}{c}\text { Result, } \\
\text { mo }(95 \% \text { CI })\end{array}$ & $\begin{array}{c}\text { 5-y survival } \\
\text { rate }(95 \% \mathrm{CI})\end{array}$ & Study groups \\
\hline $\begin{array}{r}\text { Johnstone and } \\
\text { colleagues }^{24}\end{array}$ & 2002 & RCT & 43 & Chemo & OS & $19.4(-)$ & $-(-)$ & $\mathrm{CT}+\mathrm{S}$ vs $\mathrm{CT}+\mathrm{RT}$ \\
\hline Casali and colleagues $^{25}$ & 2005 & Retrospective & 183 & None & OS & $24.0(-)$ & $20 \%(-)$ & $\mathrm{S}+\mathrm{CT}$ \\
\hline $\begin{array}{l}\text { Van Meerbeeck and } \\
\text { colleagues }^{7}\end{array}$ & 2007 & RCT & 167 & Chemo & OS & $16.4(13.3-19.0)$ & $16 \%(10-20)$ & $\mathrm{CT}+\mathrm{S}$ vs $\mathrm{CT}+\mathrm{RT}$ \\
\hline $\begin{array}{l}\text { Albain and } \\
\text { colleagues }^{6}\end{array}$ & 2009 & RCT & 202 & Chemo and RT & $\begin{array}{l}\text { OS } \\
\text { PFS }\end{array}$ & $\begin{array}{l}23.6(-) \\
12.8(-)\end{array}$ & $\begin{array}{l}27 \%(-) \\
22 \%(-)\end{array}$ & $\begin{array}{l}\mathrm{CT} \text { and } \mathrm{RT}+\mathrm{S} \text { vs } \\
\mathrm{CT}+\mathrm{RT}\end{array}$ \\
\hline Ratto and colleagues ${ }^{26}$ & 2009 & Prospective & 85 & Chemo & OS & $27.1(-)$ & $-(-)$ & $\mathrm{S}$ vs $\mathrm{CT}+\mathrm{S}$ \\
\hline Pless and colleagues ${ }^{5}$ & 2015 & RCT & $\begin{array}{l}117 \\
115\end{array}$ & $\begin{array}{c}\text { Chemo\&RT } \\
\text { Chemo }\end{array}$ & $\begin{array}{c}\text { PFS } \\
\text { OS } \\
\text { PFS } \\
\text { OS }\end{array}$ & $\begin{array}{c}12.8(9.7-22.9) \\
37.1(22.6-50.0) \\
11.6(8.4-15.2) \\
26.2(19.9-52.1)\end{array}$ & $\begin{array}{l}-(-) \\
-(-) \\
-(-) \\
-(-)\end{array}$ & $\mathrm{CT}+\mathrm{S}$ vs $\mathrm{CT}$ and $\mathrm{RT}+\mathrm{S}$ \\
\hline Current study & 2016 & Retrospective & 668 & None & $\begin{array}{l}\text { PFS } \\
\text { OS }\end{array}$ & $\begin{array}{l}17.1(14.8-19.2) \\
44.5(37.8-50.2)\end{array}$ & $\begin{array}{l}21 \%(17-25) \\
43 \%(39-47)\end{array}$ & $\mathrm{S}+\mathrm{CT} / \mathrm{RT}$ \\
\hline
\end{tabular}

$C I$, Confidence interval; $R C T$, randomized controlled trial; Chemo, chemotherapy; $O S$, overall survival; -, data not reported; $S$, surgery; $R T$, radiotherapy; $P F S$, progression-free survival.

radical resection and precise $\mathrm{N} 2$ staging potentially contributed to the surprising survival outcomes.

Moreover, postoperative adjuvant chemotherapy and radiotherapy were absolutely necessary for these patients. Therefore, R0 resection and individualized postoperative adjuvant therapy were indispensable for patients with stage IIIA NSCLC. Furthermore, both systemic adjuvant chemotherapy and selective radiotherapy after surgery were necessary for achieving better outcomes. ${ }^{34}$ All patients included in this study were recommended to receive adjuvant chemotherapy. Patients with positive margins or patients with multistation $\mathrm{N} 2$ involvement and high positive lymph node ratio $(>50 \%)$ were required to receive adjuvant radiotherapy. As a result, $84.6 \%$ of the patients received chemotherapy; the rest of the patients refused the treatment due to personal reasons. Only 15 patients were lost to follow-up as well as their treatment information. As expected, adjuvant chemotherapy could effectively prolong overall survival. The role of radiotherapy in this study was more like a supplement to surgery rather than a mean to promote prognosis.

In addition, tyrosine kinase inhibitor therapy including gefitinib and erlotinib could greatly prolong the survival of patients with EGFR mutation. ${ }^{35}$ In this study, most patients $(80.4 \%)$ received 4 to 6 full cycles of platinumbased chemotherapy. When the recurrence was confirmed, patients with $\mathrm{AD}$ with a mutated EGFR were also recommended to receive maintenance therapy of EGFR-tyrosine kinase inhibitor. Remarkably, patients with AD had significantly better overall survival and postrecurrent survival than patients with SCC. Patients with EGFR mutation had a median OS of 57 months and a 5-year OS of $47.7 \%$. EGFR mutation was more commonly seen in low-grade tumors. However, subtype analysis for AD showed that low-grade $\mathrm{AD}$ promised a similar survival to high-grade ones. Accordingly, improvement of surgical techniques and increase prevalence of lung AD with EGFR mutation may be the reason for the good prognosis of patients with stage IIIA NSCLC.

There were several limitations of our study. First, this was a retrospective, single-institution study. Conclusions made from this study were not as solid as those from prospective and multicenter studies. A randomized controlled trial on this topic is still required. Second, there were no control groups in our study. Although our data were comparable with or even superior to other published data, the results should be treated with caution because of differences in baselines as well as selection bias. Third, our strategy did not include induction chemotherapy and excluded patients who received induction chemotherapy. Therefore, some of them should have been sensitive to induction chemotherapy, thereby improving the rate of radical resection and predicting the efficacy of adjuvant therapy and extending survival. Unfortunately, such important information could not be obtained from our study. Moreover, the survival condition of these patients could also affect the prognosis of overall patients with stage IIIA NSCLC. Fourth, comparisons between surgery versus nonsurgery and surgery alone versus induction therapy were not made or analyzed in this study, although they were important topics.

Primary surgery played a central role in this study. We selected qualified patients based on our treatment algorithm to receive upfront surgery as the first-line therapy. Surgery followed by chemotherapy or chemoradiotherapy could provide a favorable prognosis compared with other reports. Hopefully, this "single-arm" retrospective study will bring new insights to thoracic surgeons. 


\section{Conflict of Interest Statement}

Authors have nothing to disclose with regard to commercial support.

\section{References}

1. Martins RG, D'Amico TA, Loo BW Jr, Pinder-Schenck M, Borghaei H, Chaft JE, et al. The management of patients with stage IIIA non-small cell lung cancer with N2 mediastinal node involvement. J Natl Compr Canc Netw. 2012;10:599-613.

2. Mehran R. The role of surgery in patients with clinical N2 disease. Thorac Surg Clin. 2013;23:327-35.

3. Van Schil PE. Stage IIIA-N2 non-small-cell lung cancer: from "surprise" involvement to surgical nightmare. Eur J Cardiothorac Surg. 2016;49:1613-4.

4. Shah AA, Berry MF, Tzao C, Gandhi M, Worni M, Pietrobon R, et al. Induction chemoradiation is not superior to induction chemotherapy alone in stage IIIA lung cancer. Ann Thorac Surg. 2013;93:1807-12.

5. Pless M, Stupp R, Ris HB, Stahel RA, Weder W, Thierstein S, et al. Induction chemoradiation in stage IIIA/N2 non-small-cell lung cancer: a phase 3 randomised trial. Lancet. 2015;386:1049-56.

6. Albain KS, Swann RS, Rusch VW, Turrisi AT III, Shepherd FA, Smith C, et al. Radiotherapy plus chemotherapy with or without surgical resection for stage III non-small-cell lung cancer: a phase III randomized controlled trial. Lancet. 2009; 374:379-86.

7. Van Meerbeeck JP, Kramer GW, Van Schil PE, Legrand C, Smit EF, Schramel F, et al. Randomized controlled trial of resection versus radiotherapy after induction chemotherapy in stage IIIA-N2 non-small-cell lung cancer. J Natl Cancer Inst. 2007;99:442-50.

8. Garelli E, Renaud S, Falcoz PE, Weingertner N, Olland A, Santelmo N, et al. Microscopic N2 disease exhibits a better prognosis in resected non-small-cell lung cancer. Eur J Cardiothorac Surg. 2016;50:322-8.

9. Liu S, Wang R, Zhang Y, Li Y, Cheng C, Pan Y, et al. Precise diagnosis of intraoperative frozen section is an effective method to guide resection strategy for peripheral small-sized lung adenocarcinoma. J Clin Oncol. 2016;34:307-13.

10. Rusch VW, Asamura H, Watanabe H, Giroux DJ, Rami-Porta R, Goldstraw P, et al. The IASLC lung cancer staging project: a proposal for a new international lymph node map in the forthcoming seventh edition of the TNM classification for lung cancer. J Thorac Oncol. 2009;4:568-77.

11. Travis WD, Brambilla E, Noguchi M, Nicholson AG, Geisinger KR, Yatabe Y, et al. International Association for the Study of Lung Cancer/American Thoracic Society/European Respiratory Society International multidisciplinary classification of lung adenocarcinoma. J Thorac Oncol. 2011;6:244-85.

12. Ujiie H, Kadota K, Chaft JE, Buitrago D, Sima CS, Lee MC, et al. Solid predominant histologic subtype in resected stage I lung adenocarcinoma is an independent predictor of early, extrathoracic, multisite recurrence and of poor postrecurrence survival. J Clin Oncol. 2015;33:2877-84.

13. National Lung Screening Trial Research Team, Aberle DR, Adams AM, Berg CD, Black WC, Clapp JD, et al. Reduced lung-cancer mortality with low-dose computed tomographic screening. N Engl J Med. 2011;365:395-409.

14. Aberle DR, DeMello S, Berg CD, Black WC, Brewer B, Church TR, et al. Results of the two incidence screenings in the National Lung Screening Trial. $N$ Engl J Med. 2013;369:920-31.

15. Roth JA, Fossella F, Komaki R, Ryan MB, Putnam JB Jr, Lee JS, et al. A randomized trial comparing perioperative chemotherapy and surgery with surgery alone in resectable stage IIIA non-small-cell lung cancer. J Natl Cancer Inst. 1994;86:673-80.

16. Rosell R, Gómez-Codina J, Camps C, Maestre J, Padille J, Cantó A, et al. A randomized trial comparing preoperative chemotherapy plus surgery with surgery alone in patients with non-small-cell lung cancer. N Engl J Med. 1994;330:153-8.

17. Nagai K, Tsuchiya R, Mori T, Tada H, Ichinose Y, Koike T, et al. A randomized trial comparing induction chemotherapy followed by surgery with surgery alone for patients with stage IIIA N2 non-small cell lung cancer (JCOG 9209). J Thorac Cardiovasc Surg. 2003;125:254-60.

18. Scagliotti GV, Pastorino U, Vansteenkiste JE, Spaggiari L, Facciolo F, Orlowski TM, et al. Randomized phase III study of surgery alone or surgery plus preoperative cisplatin and gemcitabine in stages IB and IIIA non-smallcell lung cancer. J Clin Oncol. 2012;30:172-8.

19. Van Zandwijk N, Smit EF, Kramer GW, Schramel F, Gans S, Festen J, et al. Gemcitabine and cisplatin as induction regimen for patients with biopsy-proven stage
IIIA N2 non-small-cell lung cancer: a phase II study of the European Organization for Research and Treatment of Cancer Lung Cancer Cooperative Group (EORTC 08955). J Clin Oncol. 2000;18:2658-64.

20. Burdett S, Stewart LA, Rydzewska L. A systematic review and meta-analysis of the literature: chemotherapy and surgery versus surgery alone in non-small cell lung cancer. J Thorac Oncol. 2006;1:611-21.

21. NSCLC Meta-analysis Collaborative Group. Preoperative chemotherapy for non-small-cell lung cancer: a systemic review and meta-analysis of individual participant data. Lancet. 2014;383:1561-71.

22. Gilligan D, Nicolson M, Smith I, Groen H, Dalesio O, Goldstraw P, et al. Preoperative chemotherapy in patients with resectable non-small cell lung cancer: results of the MRCLU22/NVALT 2/EORTC 08012 multicentre randomized trial and update of systematic review. Lancet. 2007;369:1929-37.

23. Eberhardt WE, Pöttgen C, Gauler TC, Friedel G, Veit S, Heinrich V, et al. Phase III study of surgery versus definitive concurrent chemoradiotherapy boost in patients with resectable stage IIIA(N2) and selected IIIB non-small-cell lung cancer after induction chemotherapy and concurrent chemoradiotherapy (ESPATUE). $J$ Clin Oncol. 2015;33:4194-201.

24. Johnstone DW, Byhardt RW, Ettinger D, Scott CB. Phase III study comparing chemotherapy and radiotherapy with preoperative chemotherapy and surgical resection in patients with non-small-cell lung cancer with spread to mediastinal lymph nodes (N2); final report of RTOG 8901. Radiation Therapy Oncology Group. Int J Radiat Oncol Biol Phys. 2002;54:365-9.

25. Casali C, Stefani A, Natali P, Rossi G, Morandi U. Prognostic factors in surgically resected N2 non-small cell lung cancer: the important of patterns of mediastinal lymph nodes metastases. Eur J Cardiothorac Surg. 2005;28:33-8.

26. Ratto GB, Costa R, Maineri P, Alloisio A, Bruzzi P, Dozin B. Is there a subset of patients with preoperative diagnosed N2 non-small cell lung cancer who might benefit from surgical resection? J Thorac Cardiovasc Surg. 2009;138:849-58.

27. Yoshino I, Yoshida S, Miyaoka E, Asamura H, Nomori H, Fujii Y, et al. Surgical outcome of Stage IIIA-cN2/pN2 non-small cell lung cancer patients in Japanese lung cancer registry study in 2004. J Thorac Oncol. 2012;7:850-5.

28. NSCLC Meta-analyses Collaborative Group, Arriagada R, Auperin A, Burdett S, Higgins JP, Johnson DH, et al. Adjuvant chemotherapy, with or without postoperative radiotherapy, in operable non-small-cell lung cancer: two meta-analyses of individual patient data. Lancet. 2010;375: 1267-77.

29. Tournoy KG, Keller SM, Annema JT. Mediastinal staging of lung cancer: novel concepts. Lancet Oncol. 2012;13:e221-9.

30. Detterbeck FC, Jantz MA, Wallace M, Vansteenkiste J, Silvestri GA; American College of Chest Physicians. Invasive mediastinal staging of lung cancer: ACCP evidence-based clinical practice guidelines (2nd edition). Chest. 2007;132(3 suppl):202S-20S.

31. National Comprehensive Cancer Network. (NCCN) Clinical Practice Guidelines in Oncology. Non-Small Cell Lung Cancer, Version 4. Available at: https://www. ncen.org/patients. Accessed December 12, 2016.

32. Eberhardt WE, De Ruysscher D, Weder W, Le Péchoux C, De Leyn P, Hoffmann $\mathrm{H}$, et al. 2nd ESMO Consensus Conference in Lung Cancer: locally advanced stage III non-small-cell lung cancer. Ann Oncol. 2015;26: 1573-88.

33. Ramnath N, Dilling TJ, Harris LJ, Kim AW, Michaud GC, Balekian AA, et al. Treatment of stage III non-small cell lung cancer: Diagnosis and management of lung cancer, 3rd ed: American College of Chest Physicians evidence-based clinical practice guidelines. Chest. 2013;143(5 suppl):e314S-40S.

34. Pignon JP, Tribodet H, Scagliotti GV, Douillard JY, Shepherd FA, Stephens RJ, et al. Lung adjuvant cisplatin evaluation: a pooled analysis by the LACE Collaborative Group. J Clin Oncol. 2008;26:3552-9.

35. Zhou C, Wu YL, Chen G, Feng J, Liu XQ, Wang C, et al. Erlotinib versus chemotherapy as first-line treatment for patients with advanced EGFR mutation-positive non-small-cell lung cancer (OPTIMAL, CTONG-0802): a multicenter, open-label, randomized, phase 3 study. Lancet Oncol. 2011;12: $735-42$.

Key Words: non-small cell lung cancer, stage IIIA, upfront surgery, progression free survival, overall survival 


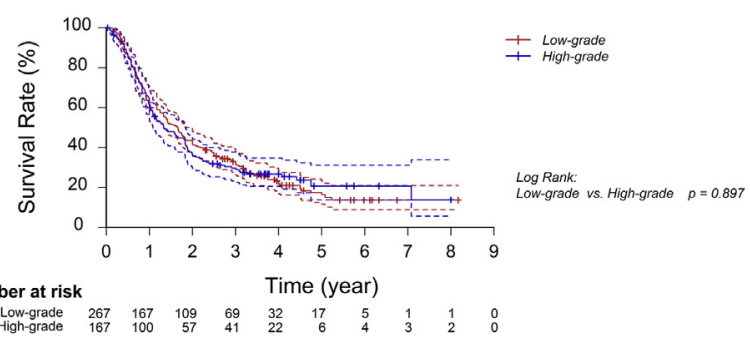

A

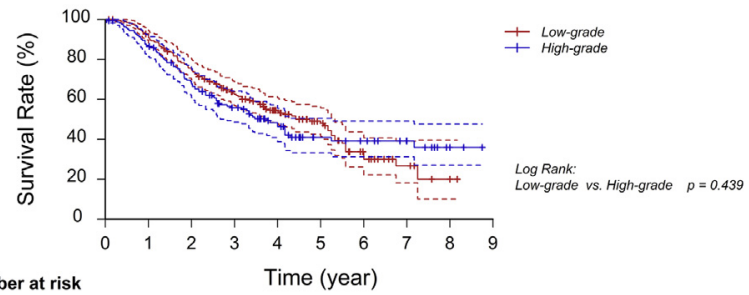

\section{B}

FIGURE E1. A, Comparison of progression-free survival between highgrade and low-grade adenocarcinoma. B, Comparison of overall survival between high-grade and low-grade adenocarcinoma. The colored dotted lines represent the $95 \%$ confidence interval for each curve.

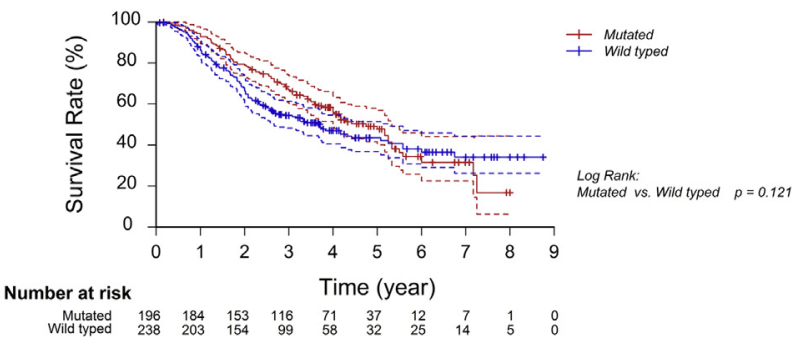

FIGURE E2. Comparison of overall survival between patients with mutated EGFR and wild-type EGFR. The colored dotted lines represent the $95 \%$ confidence interval for each curve.

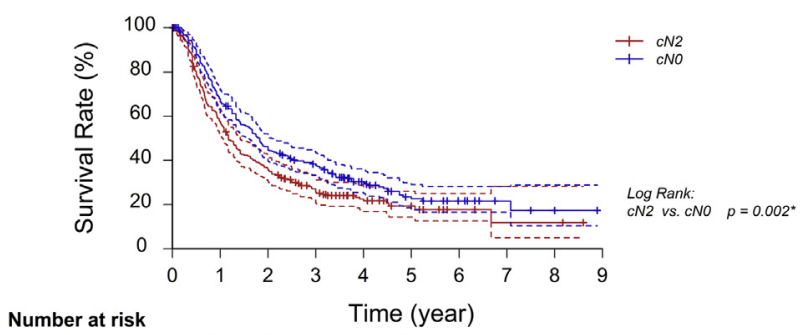

A
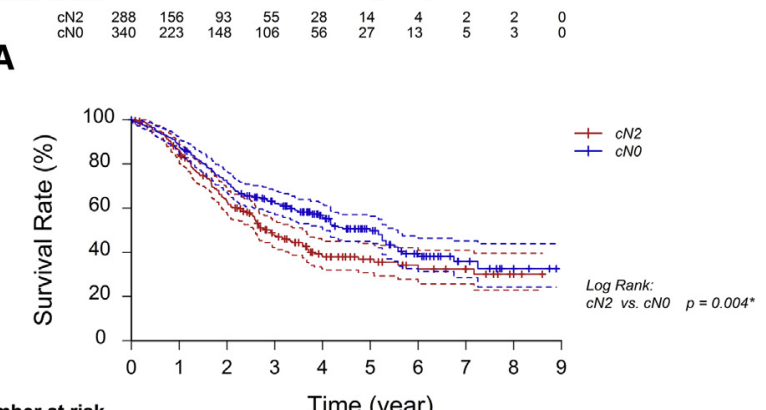

Number at risk

FIGURE E3. A, Comparison of progression-free survival between patients with clinical N0 and patients with clinical N2. B, Comparison of overall survival between patients with clinical $\mathrm{N} 0$ and patients with clinical $\mathrm{N} 2$. The colored dotted lines represent the $95 \%$ confidence interval for each curve.

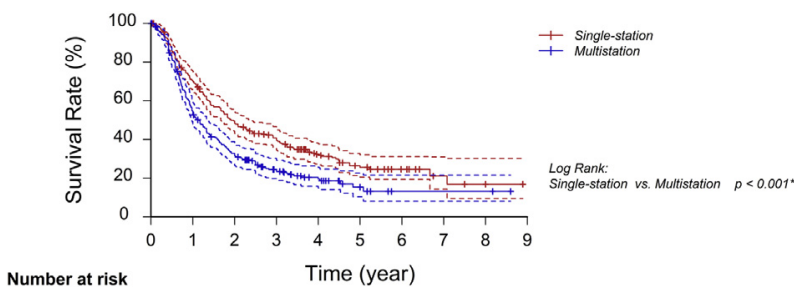

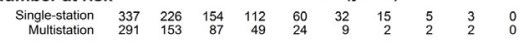

A

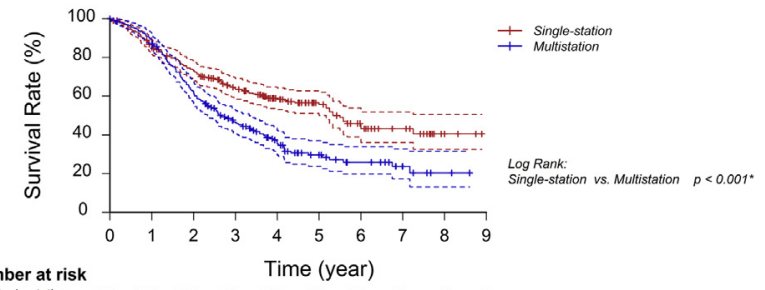

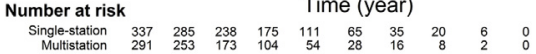

B

FIGURE E4. A, Comparison of progression-free survival between patients with single-station N2 and patients with multistation N2. B, Comparison of overall survival between patients with single-station $\mathrm{N} 2$ and patients with multistation $\mathrm{N} 2$. The colored dotted lines represent the $95 \%$ confidence interval for each curve. 
TABLE E1. Univariate analysis of PFS and OS

\begin{tabular}{|c|c|c|c|c|c|c|}
\hline \multirow[b]{2}{*}{ Parameter } & \multicolumn{3}{|c|}{ PFS } & \multicolumn{3}{|c|}{ OS } \\
\hline & HR & $95 \%$ CI for $\mathrm{HR}$ & $P$ value & $\overline{H R}$ & $95 \%$ CI for HR & $\overline{P \text { value }}$ \\
\hline \multicolumn{7}{|l|}{ Age, y } \\
\hline$>65$ & 1.093 & $0.888-1.346$ & .402 & 1.491 & $1.185-1.876$ & .001 \\
\hline$\leq 65$ & 1.0 & & & 1.0 & & \\
\hline \multicolumn{7}{|l|}{ Sex } \\
\hline Male & 1.095 & $0.909-1.319$ & .342 & 1.209 & $0.973-1.502$ & .087 \\
\hline Female & 1.0 & & & 1.0 & & \\
\hline \multicolumn{7}{|l|}{ Surgical approach } \\
\hline Muscle-sparing & 1.234 & $1.022-1.489$ & .029 & 1.440 & $1.121-1.852$ & .004 \\
\hline VATS & 1.0 & & & 1.0 & & \\
\hline \multicolumn{7}{|l|}{ Resection extent } \\
\hline Pneumonectomy and bilobectomy & 1.141 & $0.918-1.418$ & .236 & 1.528 & $1.204-1.940$ & $<.001$ \\
\hline Lobectomy & 1.0 & & & 1.0 & & \\
\hline \multicolumn{7}{|l|}{ Margin } \\
\hline Positive & 1.096 & $0.773-1.554$ & .607 & 1.370 & $1.157-1.621$ & $<.001$ \\
\hline Negative & 1.0 & & & 1.0 & & \\
\hline \multicolumn{7}{|l|}{ Tumor location } \\
\hline Central & 0.976 & $0.785-1.215$ & .831 & 1.201 & $0.937-1.538$ & .148 \\
\hline Peripheral & 1.0 & & & 1.0 & & \\
\hline \multicolumn{7}{|l|}{ Pathologic subtype } \\
\hline $\mathrm{AD}$ & 1.0 & & & 1.0 & & \\
\hline Non-AD & 0.934 & $0.769-1.135$ & .492 & 1.344 & $1.081-1.672$ & .008 \\
\hline \multicolumn{7}{|l|}{ Tumor size, $\mathrm{cm}$} \\
\hline$\leq 3$ & 1.0 & & & 1.0 & & \\
\hline$>3$ & 1.271 & $1.058-1.527$ & .010 & 1.323 & $1.068-1.637$ & .010 \\
\hline \multicolumn{7}{|l|}{ Clinical N2 status } \\
\hline Positive & 1.326 & $1.106-1.591$ & .002 & 1.360 & $1.102-1.679$ & .004 \\
\hline Negative & 1.0 & & & 1.0 & & \\
\hline \multicolumn{7}{|l|}{ Pathologic N2 status } \\
\hline Multistation & 1.507 & $1.249-1.818$ & $<.001$ & 1.715 & $1.376-2.137$ & $<.001$ \\
\hline Single-station & 1.0 & & & 1.0 & & \\
\hline \multicolumn{7}{|l|}{ Adjuvant chemotherapy } \\
\hline Yes & 1.0 & & & 1.0 & & \\
\hline No & 1.395 & $1.081-1.799$ & .010 & 2.410 & $1.866-3.106$ & $<.001$ \\
\hline \multicolumn{7}{|l|}{ Adjuvant radiotherapy } \\
\hline Yes & 1.062 & $0.862-1.308$ & .573 & 0.896 & $0.700-1.147$ & .384 \\
\hline No & 1.0 & & & 1.0 & & \\
\hline \multicolumn{7}{|l|}{ Smoking status } \\
\hline Smoker & 1.079 & $0.900-1.293$ & .413 & 1.259 & $1.021-1.554$ & .032 \\
\hline Never-smoker & 1.0 & & & 1.0 & & \\
\hline
\end{tabular}


TABLE E2. Multivariate analysis of PFS and OS

\begin{tabular}{|c|c|c|c|c|c|c|}
\hline \multirow[b]{2}{*}{ Parameter } & \multicolumn{3}{|c|}{ PFS } & \multicolumn{3}{|c|}{ OS } \\
\hline & HR & $95 \%$ CI for HR & $P$ value & HR & $95 \%$ CI for HR & $P$ value \\
\hline \multicolumn{7}{|l|}{ Age, y } \\
\hline$>65$ & & & & 1.308 & $1.006-1.702$ & .045 \\
\hline$\leq 65$ & & & & 1.0 & & \\
\hline \multicolumn{7}{|l|}{ Surgical approach } \\
\hline Muscle-sparing & & & & 1.273 & $0.977-1.659$ & .073 \\
\hline VATS & & & & 1.0 & & \\
\hline \multicolumn{7}{|l|}{ Resection extent } \\
\hline Pneumonectomy and bilobectomy & & & & 1.292 & $0.989-1.688$ & .060 \\
\hline Lobectomy & & & & 1.0 & & \\
\hline \multicolumn{7}{|l|}{ Margin } \\
\hline Positive & & & & 1.425 & $1.188-1.709$ & $<.001$ \\
\hline Negative & & & & 1.0 & & \\
\hline \multicolumn{7}{|l|}{ Tumor size, $\mathrm{cm}$} \\
\hline$\leq 3$ & 1.0 & $1.018-1.492$ & .032 & & & \\
\hline$>3$ & 1.232 & & & & & \\
\hline \multicolumn{7}{|l|}{ Clinical N2 status } \\
\hline Positive & 1.220 & $1.006-1.479$ & .043 & & & \\
\hline Negative & 1.0 & & & & & \\
\hline \multicolumn{7}{|l|}{ Pathologic N2 status } \\
\hline Multistation & 1.456 & $1.204-1.760$ & $<.001$ & 1.671 & $1.338-2.088$ & $<.001$ \\
\hline Single-station & 1.0 & & & 1.0 & & \\
\hline \multicolumn{7}{|l|}{ Adjuvant chemotherapy } \\
\hline Yes & 1.0 & & & 1.0 & & \\
\hline No & 1.311 & $1.002-1.715$ & .049 & 1.976 & $1.468-2.660$ & $<.001$ \\
\hline \multicolumn{7}{|l|}{ Smoking status } \\
\hline Smoker & & & & 1.277 & $1.018-1.601$ & .035 \\
\hline Never-smoker & & & & 1.0 & & \\
\hline
\end{tabular}

PFS, Progression-free survival; $O S$, overall survival; $H R$, hazard ratio; $C I$, confidence interval; VATS, video-assisted thoracoscopy. 
TABLE E3. Comparison of characteristics of the low-grade and high-grade groups

\begin{tabular}{|c|c|c|c|}
\hline Parameter & Low-grade group $(n=267), n(\%)$ & High-grade group $(n=167), n(\%)$ & $P$ value \\
\hline Age, mean $\pm S D$ & $59.2 \pm 10.3$ & $57.3 \pm 9.7$ & $.053^{*}$ \\
\hline Sex & & & $.174 \dagger$ \\
\hline Male & $126(47.2)$ & $90(53.9)$ & \\
\hline Female & $141(52.8)$ & $77(46.1)$ & \\
\hline Smoking status & & & $.455 \dagger$ \\
\hline Smoker & $96(36.0)$ & $66(39.5)$ & \\
\hline Never-smoker & $171(64.0)$ & $101(60.5)$ & \\
\hline Tumor location & & & $.047 \dagger$ \\
\hline Peripheral & $241(90.3)$ & $140(83.8)$ & \\
\hline Central & $26(9.7)$ & $27(16.2)$ & \\
\hline Surgical approach & & & $.163 \dagger$ \\
\hline Muscle-sparing & $235(88.0)$ & $154(92.2)$ & \\
\hline VATS & $32(12.0)$ & $13(7.8)$ & \\
\hline Resection extent & & & $.513 \dagger$ \\
\hline Lobectomy & $231(86.5)$ & $138(82.6)$ & \\
\hline Bilobectomy & $25(9.4)$ & 19 (11.4) & \\
\hline Pneumonectomy & $11(4.1)$ & $10(6.0)$ & \\
\hline Margin & & & $.090 \dagger$ \\
\hline Positive & $18(6.7)$ & $5(3.0)$ & \\
\hline Negative & $249(93.3)$ & $162(97.0)$ & \\
\hline Tumor size, $\mathrm{cm}$ & & & $<.001 *$ \\
\hline$\leq 3$ & $165(61.8)$ & $73(43.7)$ & \\
\hline$>3$ & $102(38.2)$ & $94(56.3)$ & \\
\hline $\mathrm{T}$ & & & $<.001 \dagger$ \\
\hline T1a & $51(19.1)$ & $16(9.6)$ & \\
\hline $\mathrm{T} 1 \mathrm{~b}$ & $55(20.6)$ & $23(13.8)$ & \\
\hline $\mathrm{T} 2 \mathrm{a}$ & $129(48.3)$ & $79(47.3)$ & \\
\hline $\mathrm{T} 2 \mathrm{~b}$ & $11(4.1)$ & $19(11.4)$ & \\
\hline $\mathrm{T} 3$ & $20(7.5)$ & $27(16.2)$ & \\
\hline $\mathrm{T} 4$ & $1(0.4)$ & $3(1.8)$ & \\
\hline Clinical N2 status & & & $.183 \dagger$ \\
\hline No & $169(63.3)$ & $95(56.9)$ & \\
\hline $\mathrm{N} 2$ & $98(36.7)$ & $72(43.1)$ & \\
\hline Pathologic N2 status & & & $.428 \dagger$ \\
\hline Single-station & $137(51.3)$ & $76(45.5)$ & \\
\hline Multistation & $126(47.2)$ & $82(49.1)$ & \\
\hline Adjuvant chemotherapy & & & $.124 \dagger$ \\
\hline Yes & $232(86.9)$ & $136(81.4)$ & \\
\hline No & $35(13.1)$ & $31(18.6)$ & \\
\hline Adjuvant radiotherapy & & & $.033 \dagger$ \\
\hline Yes & 79 (29.6) & $34(20.4)$ & \\
\hline No & $188(70.4)$ & 133 (79.6) & \\
\hline EGFR mutation & & & $<.001 \dagger$ \\
\hline Mutated & $154(57.7)$ & $42(25.1)$ & \\
\hline Wild-type & $113(42.3)$ & $125(74.9)$ & \\
\hline \multicolumn{4}{|l|}{ Survival } \\
\hline 5-y PFS rate & $16.4 \%$ & $20.7 \%$ & $.894 \dagger$ \\
\hline 5-y OS rate & $48.0 \%$ & $39.2 \%$ & $.439 \ddagger$ \\
\hline Median PFS, mo & $19.8 \pm 1.5$ & $16.0 \pm 2.6$ & $.894 \ddagger$ \\
\hline Median OS, mo & $57.0 \pm 5.8$ & $45.0 \pm 3.8$ & $.439 \ddagger$ \\
\hline
\end{tabular}

